\title{
The Relation of Immunoglobulin Class, Pattern of Anti- nuclear Antibody, and Complement-Fixing Antibodies to DNA in Sera from Patients with Systemic Lupus Erythematosus *
}

\author{
Naomi F. Rothfield $\ddagger$ and B. David Stollar \\ (From the Department of Medicine, New York University School of Medicine, New York, and \\ the Department of Biochemistry, Tufts University School of Medicine, \\ Boston, Massachusetts)
}

\begin{abstract}
Sera from 55 patients with systemic lupus erythematosus were studied to clarify the significance of the patterns of nuclear fluorescence observed. The sera in which the IgG fraction produced a peripheral pattern of nuclear fluorescence were found to contain complement-fixing antibodies to native DNA and to DNA-histone complexes. This correlation did not exist when complement-fixing activity was compared to the IgM nuclear patterns. Sera which contained only complement-fixing antibodies to denatured DNA and which did not react with native DNA or nucleoprotein did not produce the peripheral pattern of nuclear fluorescence. The data suggest that single strands of DNA were not the reactive groups in the nucleus responsible for the peripheral pattern. The results support the conclusion that DNA within a DNA-protein complex may be the nuclear antigen responsible for the peripheral pattern of nuclear fluorescence.

Analysis of the clinical data revealed that a close correlation existed between the presence of IgG peripheral pattern, complement-fixing antibodies to DNA and histone-DNA complexes, and clinical manifestation of active disease.
\end{abstract}

\section{Introduction}

The presence of antinuclear antibodies in sera from patients with systemic lupus erythematosus (SLE) has been described by many investigators $(1-4)$. These antibodies have been shown to be-

* Received for publication 2 May 1967 and in revised form 14 July 1967.

Presented in part at a joint meeting of the American Society for Clinical Investigation and the American Federation for Clinical Research on 30 April 1967 in Atlantic City, N. J.

This study was supported by grants from the National Institute of Allergy and Infectious Diseases (AI 06853), the Lupus Foundation, and the National Science Foundation (GB 5606).

$¥$ Clinical Scholar, The Arthritis Foundation.

Address requests for reprints to Dr. Naomi Rothfield, New York University Medical Center, School of Medicine, Department of Medicine, 550 First Avenue, New York, N. Y. 10016. long to the three major classes of immunoglobulins, i.e., IgG, IgM, and IgA (5-7). IgG antinuclear antibodies have been found in $96 \%, \operatorname{IgM}$ in $81 \%$, and $\operatorname{IgA}$ in $51 \%$ of SLE sera (7). The nuclear antigens to which these antibodies are directed have been studied by a variety of techniques including complement fixation (8-10), passive hemagglutination (2), precipitation (11-13), and agglutination of bentonite particles $(14,15)$. These studies have all shown that a variety of nuclear antigens react with various SLE sera. These antigens have been shown to be deoxyribonucleic acid (DNA), both in its native and denatured forms $(4,16,17)$, nucleoprotein (1), histone (18), a saline-soluble, periodate-sensitive antigen (19), and another similar but distinct antigen named $\mathrm{Sm}(20)$. The use of the indirect fluorescent antibody technique has led to the recognition of a 
variety of patterns of nuclear fluorescence $(7,21-$ 23). The "peripheral" or "shaggy" pattern in which nuclear fluorescence is located in an area beneath the nuclear membrane has been shown to be produced by sera which contain complementfixing, anti-DNA antibodies (23). A pattern of diffuse or homogeneous staining of nuclei is most often seen and has been shown to be abolished by pretreatment of liver sections with DNAse $(7,24)$. The speckled pattern occurs less frequently in undiluted SLE sera and has been shown to be related to the saline-soluble, periodate-sensitive antigen (22).

We have previously demonstrated that the peripheral pattern is found with sera from acutely ill SLE patients and that this is replaced by the diffuse pattern when clinical remission occurs (7). A number of investigators have shown that the anti-DNA antibodies are most often detected in sera of patients who are acutely ill $(14,25,26)$. Our present report describes the relation between the pattern of nuclear fluorescence due to IgG and $\mathrm{Ig} \mathrm{M}$ antibodies and complement-fixing antibodies to native DNA, denatured DNA, nucleoprotein, and histone-DNA complexes. The data reveal that sera which reacted in complement fixation with both nucleoprotein and native DNA uniformly caused the IgG peripheral pattern. In addition, only sera from patients with clinically active disease contained both complement-fixing antibodies to nucleoprotein and native DNA and produced the IgG peripheral pattern.

\section{Methods}

Sera. Fresh sera were obtained from 55 patients observed in the New York University Arthritis Clinic or the New York University Division of Bellevue or University Hospitals. All patients had multiple system disease typical of SLE (27) and positive LE cell preparations at some time during the course of their disease. Serum was drawn from all recently diagnosed patients and from patients in varying stages of illness as they were seen for their regular clinic visits. All laboratory tests were performed on a single sample of blood from each patient. Urinalysis was performed at the time the blood was drawn and the clinical data represent the status of the patient at the time the blood sample was obtained. The clinical status was graded as follows: grade 0 , or remission, considered to be present when the patient was asymptomatic and when fever or acute physical abnormalities were absent regardless of whether or not the patient was receiving steroids (chronic abnormalities, such as atrophic skin lesions, pigmentation, joint deformities, and chronic proteinuria, were regarded as compatible with remission); grade 1 , involvement of one system without fever, i.e., arthralgia or arthritis, rash or mucosal ulcer; grade 2, low grade fever and involvement of at least two systems or involvement of at least two systems without fever; grade 3, temperature higher than $102^{\circ} \mathrm{F}$ and involvement of at least two systems.

Fluorescent antibody test (the indirect fluorescent-antibody technic) was carried out as previously described, snap-frozen, cryostat-cut sections of mouse liver being used as a source of nuclei (6). Antisera specific for IgG and IgM were prepared in rabbits immunized with the Fc-fragment of a patient with heavy chain disease or with isolated IgM globulins, and were suitably absorbed to make them monospecific (6). These antisera were conjugated with fluorescein isothiocyanate and tested for specificity, as previously described (6). Slides were examined with an ultraviolet light source, with the use of a Leitz Ortholux microscope (E. Leitz, Inc., New York, N. Y.) with a Leitz $200 \mathrm{w}$ mercury-arc illuminator, UG1 (2 mm thickness) excitor filter and a Leitz UV-absorbing barrier filter. All slides were examined by the same observer without knowledge of the specific conjugated antiserum or patient's serum used to prepare the slide. Each serum was tested undiluted for the presence of IgG and IgM antinuclear antibody and the pattern of nuclear fluorescence was noted. In some instances, we confirmed specific immunoglobulin staining by using purified IgG from the SLE serum; we prepared the IgG globulin by diethylaminoethyl (DEAE) column chromatography, using the stepwise elution method of Lospalluto (28).

LE cell preparations were made according to the method of Zimmer and Hargraves (29). Three slides were prepared from each blood clot and were examined for at least $15 \mathrm{~min}$ each, by the same observer.

Calf thymus DNA ${ }^{1}$ was further purified by treatment with ethanol and isopropanol precipitation as described by Marmur (30). DNA was denatured by boiling for 10 $\mathrm{min}$ and then quickly chilled in an ice water bath. Deoxyribonucleoprotein (DNP) was prepared from fresh calf thymus or from thymus which had been frozen quickly after collection and stored at $-20^{\circ} \mathrm{C}$. The DNP was prepared by the procedure of Zubay and Doty, except that it was stored as a dilute suspension in iso Tris buffer $(0.14 \mathrm{M} \mathrm{NaCl}, 0.01 \mathrm{~m}$ Tris, $\mathrm{pH}$ 7.4) (31), frequently shaken, and used within 2 wk of preparation. Protein concentrations were determined by the microbiuret procedure of Itzhaki and Gill (32): samples were dialyzed against distilled water to remove the Tris buffer before proteins were estimated. The DNA content of the nucleoprotein was assayed by the diphenylamine procedure (33) and by the absorbance at $260 \mathrm{~m} \mu$ in $2 \mathrm{M}$ $\mathrm{NaCl}$.

Calf thymus histone was extracted from nucleoprotein preparations by the procedure of Johns (34). For preparations of histone-DNA complexes, the histone was dissolved in iso Tris buffer containing $1.5 \times 10^{-5} \mathrm{M} \mathrm{Ca}^{++}$and $5 \times 10^{-4} \mathrm{M} \mathrm{Mg}^{++}$, at a concentration of $12 \mu \mathrm{g} / \mathrm{ml}$. A

1 Worthington Biochemical Corporation, Freehold, N. J. 
sample of this solution was added to an equal volume of native calf thymus DNA, $5 \mu \mathrm{g} / \mathrm{ml}$, dissolved in the same buffer. The mixture was incubated at $37^{\circ} \mathrm{C}$ for $15 \mathrm{~min}$ and then diluted in the complement fixation buffer to the appropriate concentrations.

For absorption with DNP or denatured DNA, sera were diluted $1: 5$ in iso Tris buffer. The denatured DNA was converted to an insoluble gel by UV irradiation as described by Britten (35). Approximately $1.5 \mathrm{mg}$ of either of these insoluble antigens was used to absorb 1.0 $\mathrm{ml}$ of the undiluted serum, which provided an excess of antigen. For absorption with soluble native DNA, undiluted serum was used. The amount of native DNA used for absorption was estimated to provide moderate antigen excess as determined from quantitative $C^{\prime}$ fixation curves, and extrapolated to undiluted serum. After incubation at $37^{\circ} \mathrm{C}$ for $1 \mathrm{hr}$ and at $4^{\circ} \mathrm{C}$ overnight, we removed the precipitates by centrifugation. The supernatant was filtered through a membrane filter. ${ }^{2}$ Control samples of diluted serum were also centrifuged and filtered.

Rabbit antisera to denatured DNA were obtained by immunization with denatured DNA-methylated bovine serum albumin (MBSA) complexes and with nucleoside-human serum albumin (HSA) conjugates, as described and characterized previously $(36,37)$. The anti-

${ }^{2}$ C. Schleicher \& Schuell Co., Keene, N. H.
TABLE I

Immunoglobulin class and pattern of antinuclear antibody

\begin{tabular}{lcc}
\hline \hline Pattern & IgG & IgM \\
\hline Peripheral & $19^{*}$ & $16 \ddagger$ \\
Diffuse & 27 & 19 \\
Speckled & 5 & 14 \\
Negative & 4 & 6
\end{tabular}

* Three sera gave a mixture of peripheral and diffuse patterns.

$\ddagger$ Two sera gave a mixture of peripheral and diffuse patterns.

DNA-MBSA serum contained $19 \mathrm{~S}$ anti-DNA antibody and the anti-thymidine-HSA serum contained $7 \mathrm{~S}$ antiDNA antibody. Reciprocal complement fixation titers with denatured DNA under optimal assay conditions were 10,000 and 1000 , respectively.

Complement fixation technique. Quantitative microcomplement $\left(\mathrm{C}^{\prime}\right)$ fixation was performed by the technique of Wasserman and Levine (38), in a total volume of 1.2 or $7 \mathrm{ml}$, with a buffer containing $0.14 \mathrm{M} \mathrm{NaCl}, 0.01 \mathrm{M}$ Tris, $\mathrm{pH} 7.4$, with $1.5 \times 10^{-5} \mathrm{M} \mathrm{Ca}^{++}$and $5 \times 10^{-4} \mathrm{M} \mathrm{Mg}^{++}$, and $0.1 \%$ bovine serum albumin.

Duplicate samples of sera were studied independently by the indirect fluorescent antibody technique in New York and by the complement fixation method in Boston, and correlations were made after the tests were completed.

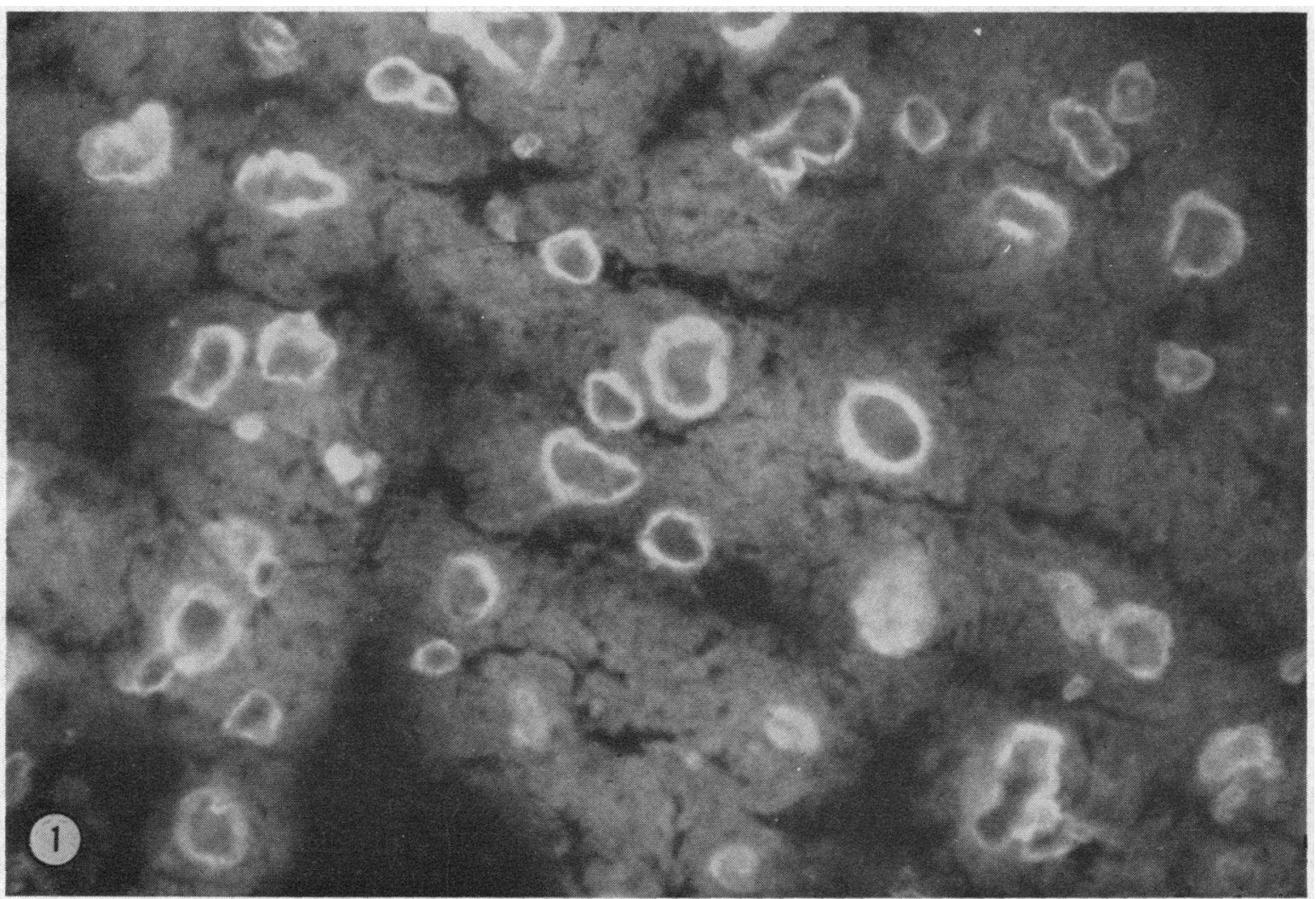

Fig. 1. THE PERIPHeRAL PATTERN OF NUCLEAR FLUORESCENCE ON A SECTION OF MOUSE LIVER. $\times 312$. 


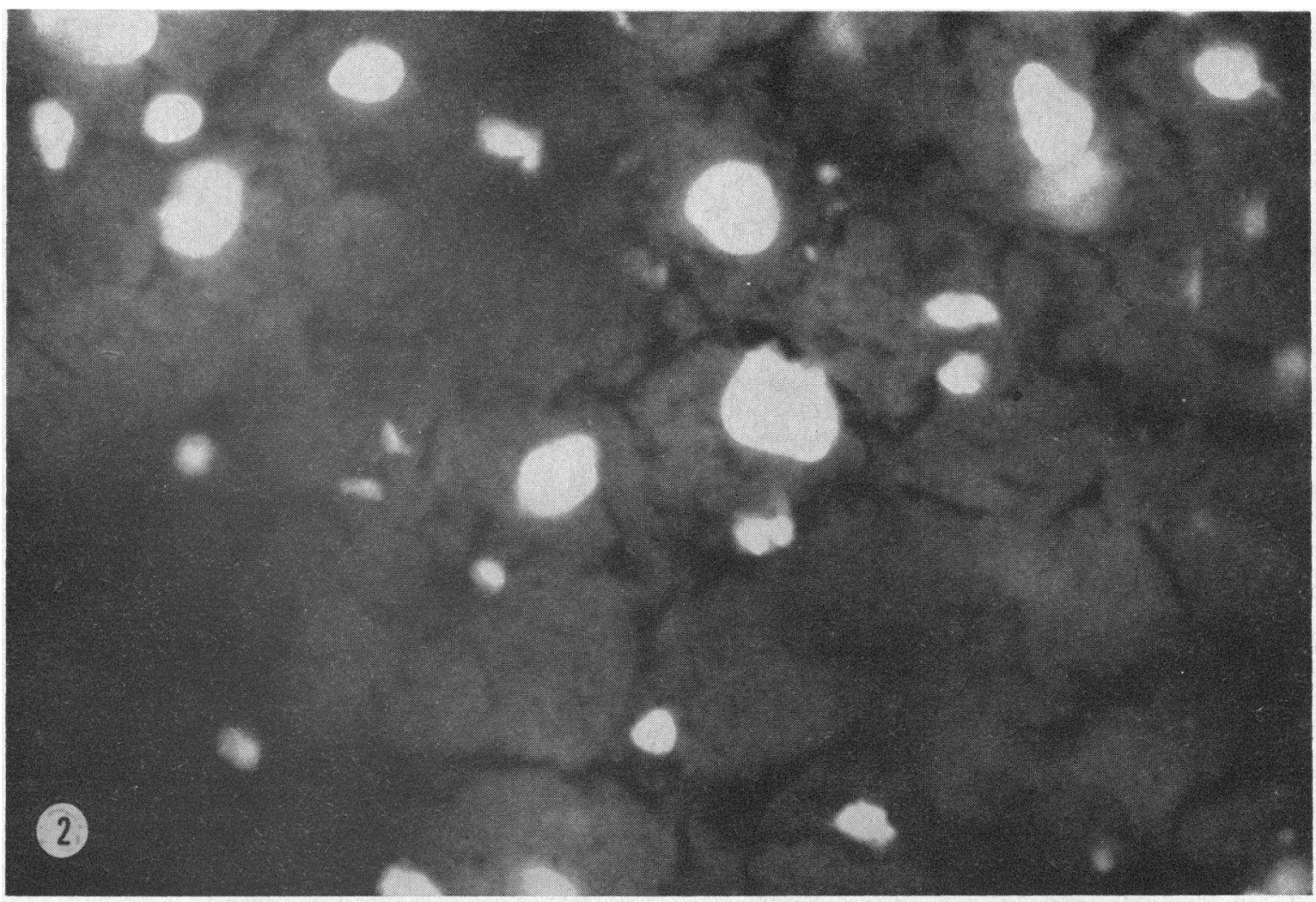

Fig. 2. The diffuse pattern of NUClear fluorescence on a SECtion OF MOUSE Liver. $\quad \times 312$.

\section{Results}

Immunoglobulin class and pattern of nuclear fuorescence. The immunoglobulin class and pattern of nuclear fluorescence present in the $\mathbf{5 5}$ sera studied are shown in Table I. The IgG antinuclear antibody was present in 51 sera and the $\operatorname{IgM}$ antinuclear antibody in 49 sera. The peripheral pattern was produced by the IgG antinuclear antibody in 19 sera and by the IgM antinuclear antibody in 16 sera (Fig. 1). The diffuse pattern (Fig. 2) was found more frequently with both $\mathrm{IgG}$ and $\operatorname{IgM}$, whereas the speckled pattern (Fig. 3) was produced by IgG antinuclear antibody in only five sera and by IgM antinuclear antibody in only 14 sera.

Complement-fixing antibodies. 13 of the 55 sera tested reacted with both native and denatured DNA, with nucleoprotein, and histone-DNA complexes (Table II). Three sera reacted with denatured DNA, histone-DNA complexes, and nucleoprotein. One serum reacted only with denatured DNA. Seven sera did not react with either form of DNA, but did react with histone-DNA complexes and with nucleoprotein. 31 sera had a negative $C^{\prime}$ fixation reaction with all of these nuclear antigens.

With the 16 sera that were positive in $\mathrm{C}^{\prime}$ fixation with either native or denatured DNA and nucleoprotein, the reactions varied in the degree of maximal $C^{\prime}$ fixation with each of the antigens (native DNA, denatured DNA, and nucleoprotein), and varied in the amount of antigen required for this maximal activity. In most instances, the amount of $\mathrm{C}^{\prime}$ fixed was greater with denatured than with native DNA (Fig. 4). In all cases, maximal $C^{\prime}$ fixation with nucleoprotein required much more antigen, in terms of DNA content or of total antigen, than was required for maximal fixation with DNA alone (Fig. 4).

Correlation of pattern of nuclear fuorescence and $C^{\prime}$-fixing antibodies. The relation between the presence of a peripheral pattern of nuclear fluorescence due to $\operatorname{IgG}$ and IgM and the $C^{\prime}$-fixing, anti-DNA antibodies is shown in Table III. Of the 17 sera which contained $C^{\prime}$-fixing antibodies to either native or denatured DNA, the 


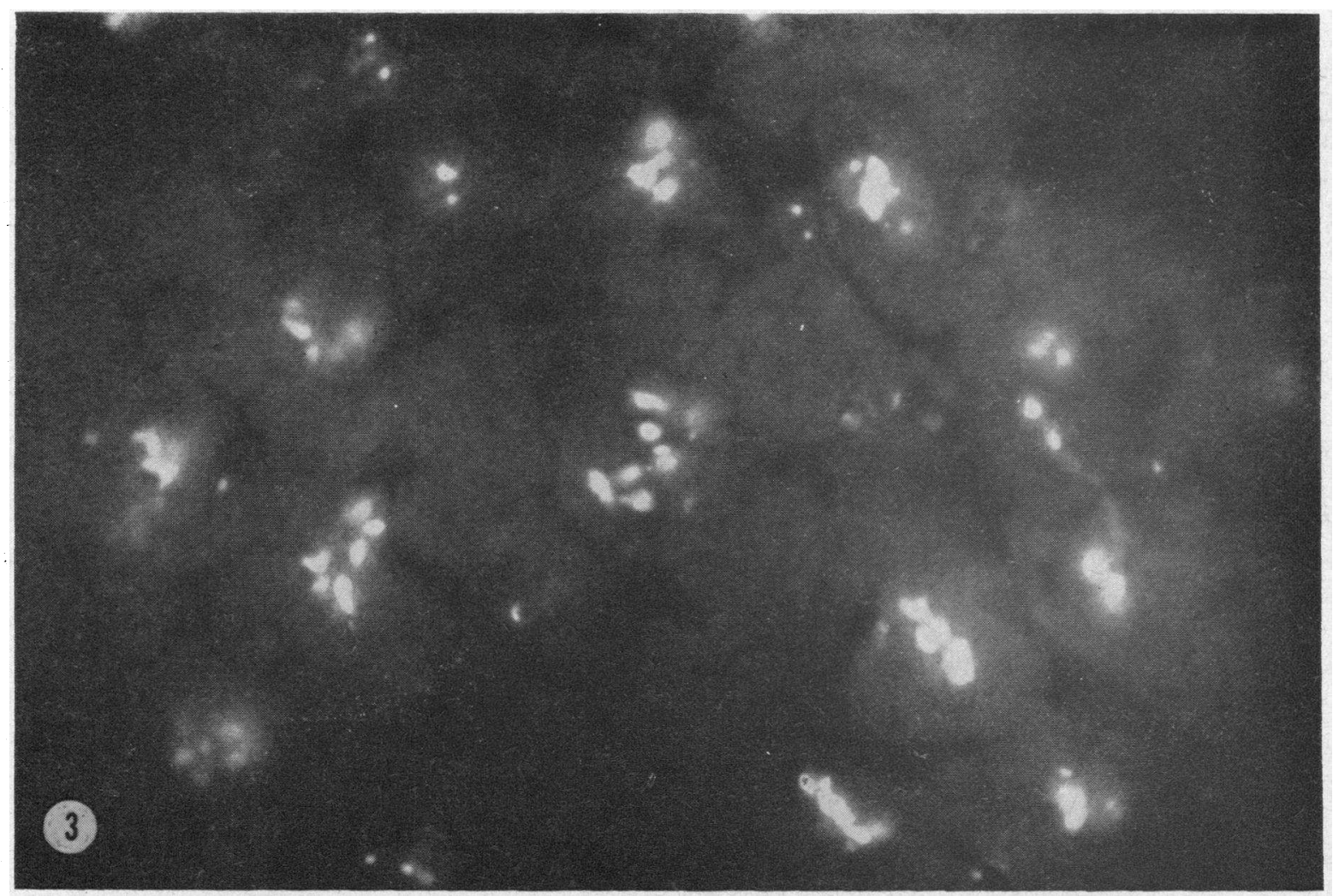

Fig. 3. The SPECKLED PATTERN OF NUCLEAR FLUORESCENCE ON A SECTION OF MOUSE Liver. $\times 312$.

IgG peripheral pattern was produced by 16 sera and the IgM peripheral pattern by 7 sera. Of the 38 sera which did not contain antibodies to either native or denatured DNA, the IgG peripheral pattern was present with three sera and the IgM peripheral pattern with nine sera. The peripheral pattern due to the IgG was present with 16 of the 17 sera containing antibodies to either native or denatured DNA. On the other hand, the IgM peripheral pattern was produced by 7 of the 17 $\mathrm{C}^{\prime}$ fixation positive sera and by 9 of the $38 \mathrm{C}^{\prime}$ fixation negative sera and, thus, did not correlate

TABLE II

Incidence of $C^{\prime}$-fixing antibodies to various nuclear antigens

\begin{tabular}{ccccc}
\hline \hline \multirow{4}{*}{$\begin{array}{c}\text { No. of } \\
\text { sera }\end{array}$} & $\begin{array}{c}\text { Native } \\
\text { DNA }\end{array}$ & $\begin{array}{c}\text { Denatured } \\
\text { DNA }\end{array}$ & $\begin{array}{c}\text { Histone- } \\
\text { DNA }\end{array}$ & DNP \\
\hline 13 & + & + & + & + \\
3 & - & + & + & + \\
1 & - & + & - & + \\
31 & - & - & - & + \\
\hline
\end{tabular}

+ , reaction; - , no reaction. with the presence of antibodies to native or denatured DNA.

The relation between the $C^{\prime}$-fixing antibodies to all the nuclear antigens tested and the IgG peripheral pattern is shown in Table IV. The largest group of sera, group I, was negative in $C^{\prime}$ fixation with all antigens and had an IgG diffuse or speckled pattern or no IgG antinuclear antibody. 16 sera, group II, reacted in $C^{\prime}$ fixation with either denatured DNA or both native and denatured DNA, with histone-DNA complexes, and with nucleoprotein, and had an IgG peripheral pattern. The single serum, group III, which reacted with denatured DNA but with neither native DNA nor nucleoprotein, had an IgG diffuse pattern. Three sera, group IV, had a peripheral IgG pattern and reacted in $C^{\prime}$ fixation with nucleoprotein, but not with native or denatured DNA. A final group of four sera, group $\mathrm{V}$, fixed $\mathrm{C}^{\prime}$ with nucleoprotein but with neither native nor denatured DNA, and had an IgG diffuse pattern. Every serum which fixed $C^{\prime}$ with both DNA and nucleoprotein and histone- 


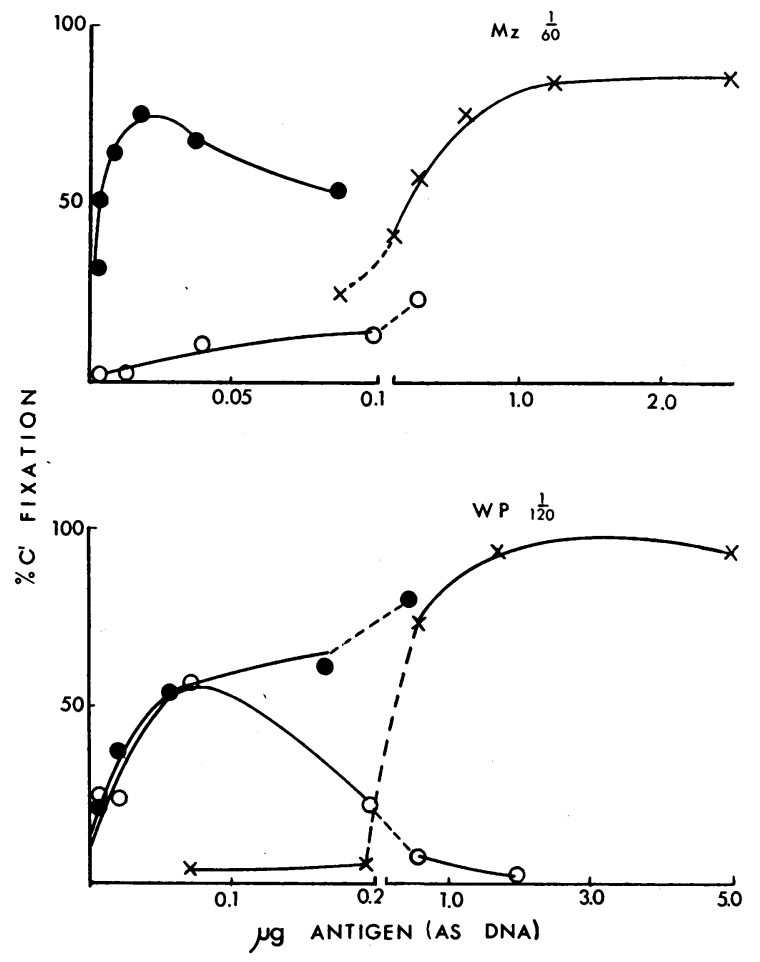

Fig. 4. C' FiXation With SLE SERA $M z(1 / 60)$ AND WP (1/120) and Native DNA (O), Denatured DNA $(\bullet)$, AND NUCleoprotein $(X)$.

DNA complexes produced the IgG peripheral pattern.

To test further whether anti-denatured DNA antibody could be involved in producing the peripheral pattern of nuclear fluorescence, experimentally induced rabbit antibodies which reacted only with denatured DNA were studied. The rabbit antibodies to DNA were $19 \mathrm{~S}$ antibodies induced by immunization with DNA-MBSA complexes and $7 \mathrm{~S}$ antibodies induced by immunization with thymidine-HSA conjugates. Using these sera and a fluorescein-conjugated antirabbit globulin, we observed no nuclear fluorescence.

Absorption studies. Absorption studies carried out with a serum from group II, Table IV, are

TABLE III

Incidence of IgG and IgM peripheral pattern in sera with and without $C^{\prime}$-fixing, anti-DNA antibodies

\begin{tabular}{cccc}
\hline & No. of sera & IgG & IgM \\
\hline + C'-fixing with DNA & 17 & 16 & 7 \\
- C'-fixing with DNA & 38 & $3^{*}$ & 9 \\
\hline
\end{tabular}

* These sera contained C'-fixing anti-histone DNA.
TABLE IV

Correlation of $C^{\prime}$-fixing antibodies and IgG pattern of nuclear fuorescence

\begin{tabular}{lrlcll}
\hline \hline & & \multicolumn{4}{c}{ C' fixation $^{\text {No. of }}$} \\
\cline { 3 - 6 } & sera & DNA & $\begin{array}{c}\text { Histone- } \\
\text { DNA }\end{array}$ & DNP & IgG pattern \\
\hline Group I & 31 & - & - & - & $\mathrm{D}, \mathrm{S}$, or Neg \\
Group II & 16 & + & + & + & $\mathrm{P}$ \\
Group III & 1 & $+^{*}$ & - & - & $\mathrm{D}$ \\
Group IV & 3 & - & + & + & $\mathrm{P}$ \\
Group V & 4 & - & + & + & $\mathrm{D}$
\end{tabular}

$D$, diffuse; $S$, speckled; $P$, peripheral; Neg. negative.

* Positive with denatured DNA, negative with native DNA.

shown in Fig. 5. This serum had complementfixing antibodies to all nuclear antigens tested and an IgG peripheral pattern of nuclear fluorescence. Absorption with native or denatured DNA or with nucleoprotein removed the peripheral IgG pattern (Table V), but left a speckled pattern. The presence of a variety of antibody populations was further indicated by the fact that residual antinucleoprotein activity remained after absorption with DNA. On the other hand, absorption with
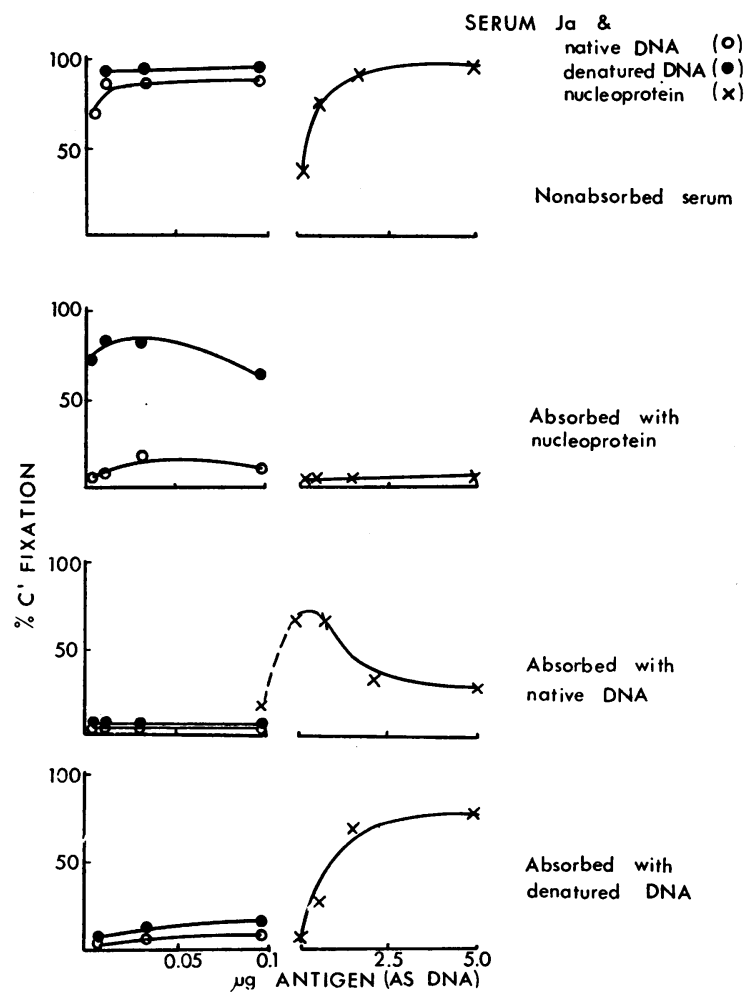

Fig. 5. C' FIXATION OF UNABSORBED AND ABSORBED SLE SERUM JA (1/300) with NATIVE DNA (O), DENATURED DNA ( () , AND NUCLEOPROTEIN $(X)$. 
TABLE V

Absorption studies with a serum from Group II

\begin{tabular}{lcccc}
\hline \hline & & \multicolumn{4}{c}{$\begin{array}{c}\text { Remaining \% } C^{\prime} \text {-fixing } \\
\text { (serum diluted 1/300) }\end{array}$} \\
\cline { 3 - 5 } \cline { 4 - 5 } $\begin{array}{c}\text { Serum ab- } \\
\text { sorbed with }\end{array}$ & $\begin{array}{c}\text { Remaining } \\
\text { titer of IgG } \\
\text { peripheral } \\
\text { pattern }\end{array}$ & $\begin{array}{c}\text { Native } \\
\text { DNA }\end{array}$ & $\begin{array}{c}\text { De- } \\
\text { natured } \\
\text { DNA }\end{array}$ & Nucleoprotein \\
\hline Denatured DNA & 320 & 88 & 95 & 93 \\
Native DNA & 10 & 10 & 10 & 75 \\
Nucleoprotein & 0 & 0 & 0 & 60 \\
& 0 & 16 & 65 & 6 \\
\hline
\end{tabular}

nucleoprotein left $\mathrm{C}^{\prime}$-fixing antibody to denatured DNA, but removed the antibody to native DNA. Native or denatured DNA absorbed the antibodies to both forms of DNA. The antibody to denatured DNA, which remained after absorption with nucleoprotein, did not produce the peripheral pattern of nuclear fluorescence. In this respect, this absorbed serum resembled the serum of group III (Table IV) in which only antibody against denatured DNA was present and the peripheral pattern was not found.

Three other sera from group II (Table IV) were also examined in absorption studies. With one serum, absorption with native or denatured DNA or nucleoprotein completely removed the IgG peripheral pattern of nuclear fluorescence. With the other two sera, native or denatured DNA alone did not remove the peripheral pattern whereas absorption with nucleoprotein removed it completely.

Absorption studies were carried out with one of the three sera in group IV (Table IV) which reacted in $\mathrm{C}^{\prime}$ fixation only with nucleoprotein and which produced an IgG peripheral pattern of nuclear fluorescence. Absorption with native DNA removed the peripheral IgG pattern and the $\mathrm{C}^{\prime}$ fixing antibody to nucleoprotein (Table VI). Absorption with denatured DNA removed most of the peripheral IgG staining but left nearly all
TABLE VI

Absorption studies with a serum from Group IV

\begin{tabular}{|c|c|c|c|c|}
\hline \multirow[b]{2}{*}{$\begin{array}{l}\text { Serum ab- } \\
\text { sorbed with }\end{array}$} & \multirow{2}{*}{$\begin{array}{c}\text { Remaining } \\
\text { reciprocal } \\
\text { titer of IgG } \\
\text { peripheral } \\
\text { pattern }\end{array}$} & \multicolumn{3}{|c|}{$\begin{array}{l}\text { Remaining } C^{\prime} \text {-fixing antibodies } \\
\text { (serum diluted } 1 / 100 \text { ) }\end{array}$} \\
\hline & & $\begin{array}{c}\text { Native } \\
\text { DNA }\end{array}$ & $\begin{array}{c}\text { De- } \\
\text { natured } \\
\text { DNA }\end{array}$ & Nucleoprotein \\
\hline- & 80 & 0 & 0 & 95 \\
\hline Denatured DNA & 20 & 0 & 0 & 86 \\
\hline Native DNA & 0 & 0 & 0 & 0 \\
\hline Nucleoprotein & 0 & 0 & 0 & 0 \\
\hline
\end{tabular}

of the $\mathrm{C}^{\prime}$-fixing antinucleoprotein antibody in the serum.

In absorption studies, when absorption with either DNA or nucleoprotein was effective the speckled pattern of nuclear fluorescence was noted or no fluorescence was present.

Clinical characteristics. The patients were divided into groups according to the degree of clinical activity at the time the blood was obtained for study of the antinuclear antibodies (Table VII). Of the 26 patients with grade 0 activity, none had the IgG peripheral pattern of nuclear fluorescence and none had anti-DNA, $\mathrm{C}^{\prime}$-fixing antibodies. On the other hand, of the 15 patients with severe disease, the IgG peripheral pattern was present in 13 patients, all of whose sera had anti-DNA, C'fixing antibodies. There was no correlation between the presence of $\operatorname{IgM}$ peripheral pattern and degree of clinical activity.

Proteinuria was present in 21 patients. 13 of these patients had anti-DNA, $\mathrm{C}^{\prime}$-fixing antibodies and showed the IgG peripheral pattern of nuclear fluorescence. Hematuria was present in nine of the 55 patients studied. All patients with hematuria had clinically active disease in other systems, and their sera produced the IgG peripheral pattern and contained $\mathrm{C}^{\prime}$-fixing, anti-DNA antibodies. Renal insufficiency (elevation of the blood urea nitrogen to greater than $30 \mathrm{mg} / 100 \mathrm{ml}$ ) was pres-

TABLE VII

Relation of clinical disease activity to presence of peripheral pattern and $C^{\prime}$-fixing anti-DNA and anti-histone DNA

\begin{tabular}{|c|c|c|c|c|c|c|c|c|c|}
\hline \multirow{2}{*}{$\begin{array}{l}\text { Degree of } \\
\text { clinical } \\
\text { activity }\end{array}$} & \multirow{2}{*}{$\begin{array}{l}\text { No. of } \\
\text { patients }\end{array}$} & \multirow{2}{*}{$\begin{array}{l}\text { Positive } \\
\text { LE } \\
\text { prepar- } \\
\text { ation }\end{array}$} & \multicolumn{2}{|c|}{$C^{\prime}$-fixing } & \multicolumn{2}{|c|}{$\begin{array}{l}\text { Peripheral } \\
\text { pattern }\end{array}$} & \multicolumn{3}{|c|}{ Renal manifestations } \\
\hline & & & DNA & DNA & IgG & IgM & Prot & Hemat & BUN $\uparrow$ \\
\hline $\begin{array}{l}0 \\
1 \\
2 \\
3\end{array}$ & $\begin{array}{r}26 \\
7 \\
7 \\
15\end{array}$ & $\begin{array}{r}4 \\
4 \\
4 \\
14\end{array}$ & $\begin{array}{r}0 \\
1 \\
3 \\
13\end{array}$ & $\begin{array}{r}4 \\
2 \\
3 \\
14\end{array}$ & $\begin{array}{r}0 \\
2 \\
3 \\
13\end{array}$ & $\begin{array}{l}2 \\
4 \\
3 \\
5\end{array}$ & $\begin{array}{r}4 \\
4 \\
1 \\
12\end{array}$ & $\begin{array}{l}0 \\
0 \\
0 \\
9\end{array}$ & $\begin{array}{l}0 \\
0 \\
0 \\
8\end{array}$ \\
\hline
\end{tabular}

LE, lupus erythematosus; Prot, proteinuria; Hemat, hematuria; BUN, blood urea nitrogen. 
ent in eight patients. In all of these patients, the sera contained anti-DN.A, $C^{\prime}$-fixing antibodies and produced the IgG peripheral pattern.

\section{Discussion}

The presence of the peripheral pattern of nuclear fluorescence produced by sera of patients with clinically active SLE was first noted by Casals et al. (23), with peripheral blood leukocytes. The "shaggy" pattern, reported by these investigators, is probably similar to our "peripheral" pattern and to the "membranous" pattern described by Beck (24). In a previous study of 100 SLE patients, the incidence of the peripheral pattern in patients with grade 2-3 activity was found to be significantly higher than in patients with grade $0-1$. In addition, the peripheral pattern was not found in sera from patients with other diseases. ${ }^{3}$

The correlation between the presence of antiDNA antibodies and active SLE was first noted by Seligmann who used the complement fixation technique (4) and his original observation has been subsequently confirmed by others using different methods for detecting antibodies to DNA $(14,27,39,40)$.

The data reported here reveal a strong correlation between the presence of IgG peripheral pattern, anti-DNA antibodies, and disease activity. The presence of anti-DNA antibodies in all patients with hematuria and renal insufficiency supports the suggestion of Tan et al. that the renal lesion of SLE may be due to a circulating complex of anti-DNA and DNA (41). These investigators found free circulating DNA in sera of patients with SLE who were acutely ill, and anti-DNA antibodies were subsequently detected in the sera of the same patients.

The data revealed a close correlation between the presence of $\operatorname{IgG}$ peripheral staining antinuclear activity and the presence of antibodies which reacted in $\mathrm{C}^{\prime}$ fixation with both DNA and histoneDNA complexes. This correlation did not exist when $\mathrm{C}^{\prime}$ fixation activity was compared to $\operatorname{IgM}$ nuclear staining. The latter finding may be related to the fact that some IgM antibodies have failed to react in this system with certain antigenic structures (37).

${ }^{3}$ Rothfield, N. F. Unpublished data.
Further studies were carried out in an attempt to define the antigen involved in IgG peripheral staining. Casals et al. have indicated that, at least with some sera, DNA made a major contribution to these determinants $(23)$.

Whereas most SLE sera contain antibodies which reacted better with denatured than with native DNA (17), the serum which reacted with only the denatured form and which did not react with native DNA or nucleoprotein did not cause peripheral nuclear staining. Furthermore, rabbit antibodies which reacted with only denatured DNA did not produce any nuclear staining. Thus, single strands of the nucleic acids were not the reactive groups in the nucleus.

The correlation of activities was closest with sera reacting with both DNA and histone-DNA complexes. In addition, DNA alone showed variable ability to completely absorb IgG peripheral staining antibody, whereas absorption with DNP always removed the peripheral staining activity. Thus, it appeared that the determinants responsible for peripheral staining involved native DNA within nucleoprotein structures and that specific determinants differed for different sera just as determinants for SLE anti-DNA antibodies have been found to vary for different sera $(17,42,43)$. The different relative reactivities with native DNA and DNP probably reflected the varying contributions of DNA to the antigenic determinant structures within the DNP or the possibility that the configuration of DNA in the nucleus differs from DNA in solution. As noted, maximal $C^{\prime}$ fixation with nucleoprotein required 10-50 times as much DNA content as when free DNA reacted, even when the nucleic acid formed the major part of the DNP determinant as in those cases where free DNA could absorb most of the anti-DNP antibody. Thus, the $\mathrm{C}^{\prime}$ fixation studies indicated that only a portion of the total DNA in the DNP was available and in the appropriate form for reaction with the antibody. Many sera must be studied individually in order to identify the full range of possible determinant structures.

The peripheral location of the appropriately organized DNA-protein complex in the nucleus either in nature or as a result of the methods used to prepare the sections is not characteristic of all cells, and the choice of substrate is important in studying this structure; circulating human leuko- 
cytes did not show the same localization as mouse liver cells. ${ }^{4}$

The use of antinuclear antibodies of differing specificity, combined with the fluorescent localization technique, may prove to be a helpful tool in studies of intranuclear organization of DNA and nucleoprotein.

\section{Acknowledgments}

We are grateful for the technical assistance of Mrs. Maureen Toulon, Miss Bianca Pollio, and Mrs. Hollace Cole.

\section{References}

1. Holman, H. R., and H. G. Kunkel. 1957. Affinity between the lupus erythematosus serum factor and cell nuclei and nucleoprotein. Science. 126: 162.

2. Miescher, P., and R. Strassle. 1957. New serological methods for the detection of the L.E. factor. Vox Sanguinis. 2: 283.

3. Friou, G. J. 1958. Identification of the nuclear component of the interaction of lupus erythematosus globulin and nuclei. J. Immunol. 80: 476.

4. Seligmann, M. 1958. Etudes immunologiques sur le lupus érythémateux disseminé. Rev. Franc. Etudes Clin. Biol. 3 : 558.

5. Barnett, E. V., J. J. Condemi, J. P. Leddy, and J. H. Vaughan. 1964. Gamma antinuclear factors in human sera. J. Clin. Invest. 43: 1104.

6. Rothfield, N. F., B. Fragione, and E. C. Franklin. 1965. Slowly sedimenting mercaptoethanol-resistant antinuclear factors related antigenically to M immunoglobulins ( $\gamma_{1 \mathrm{M}}$ globulin) in patients with systemic lupus erythematosus. J. Clin. Invest. 44 : 62.

7. Gonzalez, E. N., and N. F. Rothfield. 1966. Immunoglobulin class and pattern of nuclear fluorescence in ssytemic lupus erythematosus. New Engl. J. Med. 274 : 133.

8. Robbins, W. C., H. R. Holman, H. R. Deicher, and H. G. Kunkel. 1957. Complement fixation with cell nuclei and DNA in lupus erythematosus. Proc. Soc. Exptl. Biol. Med. 96: 575.

9. Seligmann, M. 1957. Leuco-préciptines II. Mise en évidence d'une reáction de precipitation entre des extraits leucocytaires et le sérum de malades attients de lupus érythémateux disséminé. Vox Sanguinis. 2: 270.

10. Pearson, C. M., C. G. Craddock, and N. S. Simmons. 1958. Complement fixation reaction with DNA and leucocyte material in systemic lupus erythematosus. Correlation with the L.E. cell phenomenon and the clinical status. J. Lab. Clin. Med. 52: 580 .

4 Rothfield, N. F. Unpublished data.
11. Cepellini, R. C. Polli, and F. Celada. 1957. A DNA-reacting factor in serum of a patient with lupus erythematosus diffusus. Proc. Soc Exptl. Biol. Med. 96 : 572.

12. Seligmann, M., and F. Milgrom. 1957. Mise en évidence par la fixation du complement de la réaction entre acide désoxyribonucléique et serum de malades atteints de lupus érythémateux disséminé. Centre Rech. Acad. Sci. (Paris). 245 : 1472.

13. Anderson, J. R., K. G. Gray, J. S. Beck, W. W. Buchanan, and A. J. McElhinney. 1962. Precipitating auto-antibodies in the connective tissue diseases. Ann. Rheumatic Diseases. 21: 360.

14. Kayhoe, D. E., J. P. Nasou, and J. Bozicevich. 1960. Clinical evaluation of the DNA-bentonite flocculation test for systemic lupus erythematosus. New Engl. J. Med. 263: 5.

15. Sturgill, B. C., R. R. Carpenter, A. J. L. Strauss, and H. C. Goodman. 1964. Antibodies in Systemic Lupus Erythematosus and myasthenia gravis which react with thermally denatured DNAcoated bentonite. Proc. Soc. Exptl. Biol. Med. 115 : 246.

16. Diecher, H. R. G., H. R. Holman, and H. G. Kunkel. 1959. The precipitin reaction between DNA and a serum factor in systemic lupus erythematosus. J. Exptl. Med. 109 : 97.

17. Stollar, D., L. Levine, and J. Marmur. 1962. Antibodies to denatured deoxyribonucleic acid in lupus erythematosus serum. II. Characterization of antibodies in several sera. Biochim. Biophys. Acta. $61: 7$.

18. Holman, H., and H. R. Deicher. 1959. The reaction of lupus erythematosus (L.E.) cell factor with deoxyribonucleoprotein of the cell nucleus. J. Clin. Invest. 38: 2059.

19. Holman, H. R. 1965. Partial purification and characterization of an extractable nuclear antigen which reacts with SLE sera. Ann. N. Y. Acad. Sci. 124: 800 .

20. Tan, E. M., and H. G. Kunkel. 1966. Characteristics of a soluble nuclear antigen precipitating with sera of patients with systemic lupus erythematosus. J. Immunol. $96: 464$.

21. Beck, J. S. 1961. Variations in the morphologic patterns of "autoimmune" nuclear fluorescence. Lancet. I: 1203.

22. Lackmann, P. J., and H. G. Kunkel. 1961. Correlation of antinuclear antibodies to nuclear staining patterns. Lancet. II : 436.

23. Casals, S. P., G. J. Friou, and P. O. Teague. 1963. Specific nuclear reaction pattern of antibody to DNA in lupus erythematosus sera. J. Lab. Clin. Med. $62: 625$.

24. Beck, J. S. 1963. Auto-antibodies to cell nuclei. Scot. Med. J. 8: 373.

25. Casals, S. P., G. J. Friou, and L. L. Myers. 1964. Significance of antibody to DNA in systemic lupus erythematosus. Arthritis Rheumat. $7: 379$. 
26. Cannat, A., and M. Seligmann. 1965. Les anticorps anti-nucléaires décelés par immunofluorescence et par d'autres méthods immunologiques. Semaine Hôp. Paris. 41: 1090.

27. Rothfield, N. F., J. M. Phythyon, C. McEwen, and P. Miescher. 1961. The role of antinuclear reactions in the diagnosis of systemic lupus erythematosus. A study of 53 cases. Arthritis Rheumat. 4: 223.

28. Lospalluto, J., and M. Ziff. 1959. Chromatographic studies of the rheumatoid factor. J. Exptl. Med. 110: 169.

29. Zimmer, F. F., and M. M. Hargraves. 1952. The effect of blood coagulation on L.E. cell formation. Proc. Staff Meetings Mayo Clinic. 27 : 424.

30. Marmur, J. 1961. A procedure for the isolation of deoxyribonucleic acid from micro-organisms. $J$. Mol. Biol. 3 : 208.

31. Zubay, G., and P. Doty. 1959. The isolation and properties of deoxyribonucleoprotein particles containing single nucleic acid molecules. J. Mol. Biol. $1: 1$.

32. Itzhaki, R. F., and D. M. Gill. 1964. A micro-biuret method for estimating proteins. Anal. Biochem. 9: 401.

33. Dische, Z. 1955. Color reactions of nucleic acid components. In The Nucleic Acids. E. Chargaff and J. N. Davidson, editors. Academic Press Inc., New York. $1: 285$.

34. Johns, E. W. 1967. Studies on histones. 7. Preparative methods for histone fractions from calf thymus. Biochem. J. 92: 55.

35. Britten, R. J. 1963. Complementary strand association between nucleic acids and nucleic acid gels. Science. 142: 963.
36. Stollar, B. D., and A. L. Sandberg. 1966. Comparisons of antibodies reacting with DNA. I. Systemic lupus erythematosus sera and rabbit antibodies induced by DNA-methylated bovine serum albumin complexes. J. Immunol. $96: 755$.

37. Sandberg, A. L., and B. D. Stollar. 1966. Comparisons of antibodies reacting with DNA. II. Rabbit antibodies induced by nucleoside-protein conjugates. J. Immunol. 96: 764 .

38. Wasserman, E., and L. Levine. 1961. Quantitative micro-complement fixation and its use in the study of antigenic structure by specific antigen-antibody inhibition. J. Immunol. 87: 290.

39. Jokinen, E. J., and H. Julkunen. 1965. DNA hemagglutination test in the diagnosis of systemic lupus erythematosus. Ann. Rheumatic Diseases. 24 : 477.

40. Hamard, M., A. Cannat, and M. Seligmann. 1964. $\mathrm{La}$ récherche d'anticorps anti-nucléaires par immunofluorescence (Etude de 1430 serums). Rev. Franc. Etudes Clin. Biol. 9: 716.

41. Tan, E. M., P. H. Schur, R. I. Carr, and H. G. Kunkel. 1966. Deoxyribonucleic acid (DNA) and antibodies to DNA in the serum of patients with lupus erythematosus. J. Clin. Invest. 45: 1732.

42. Stollar, D., L. Levine, H. I. Lehrer, and H. Van Vunakis. 1962. The antigenic determinants of denatured DNA reactive with lupus erythematosus serum. Proc. Natl. Acad. Sci. 48: 874.

43. Stollar, D., and L. Levine. 1963. Antibodies to denatured deoxyribonucleic acid in lupus erythematosus serum. IV. Evidence for purine determinants in DNA. Arch. Biochim. Biophys. 101: 417. 